\title{
Analisis Putusan Pengadilan Agama Sukabumi pada Perkara Nomor. 0493/Pdt.G/2020/Pa.Smi Perihal Harta Bersama yang Mengandung Hawalah
}

\author{
Siti Rahmi Fadila* \\ Prodi Hukum Keluarga Islam, Fakultas Syariah, Universitas Islam \\ Bandung, Indonesia. \\ *sitirahmifadila17@gmail.com
}

\begin{abstract}
This writing is motivated by the transfer of debt (Hawalah) as an Effort of Legality of Joint Property Ownership or in Indonesia it is also called gono-gini property where it is the entire wealth that is unanimously obtained during the marriage period. This problem is one of the legal consequences that are always present after divorce, while the transfer of debt in joint assets is a rare case, therefore the author intends to study more deeply about joint assets containing Hawalah or transfer of debts such as a lawsuit that goes to the Sukabumi religious court. on case number. 0493/Pdt.G/2020/PA.Smi. This research is a normative legal research. The sources and types of legal materials used are primary legal materials supported by secondary legal materials and then analyzed using qualitative normative methods in the form of descriptions to draw conclusions in order to obtain clarity on the problems studied. Based on the results of research and discussion, conclusions are drawn, namely, First, on the judge's consideration in case No. 0493/Pdt.G/2020/PA.Smi. This article uses article 97 of the Compilation of Islamic Law as a legal basis. Second, the transfer of debt in an effort to legalize joint property ownership cannot be granted by the panel of judges because the joint property has not been divided in real terms. Third, the lawsuit was partially granted because the plaintiff did not fully provide legal evidence for the arguments of his lawsuit.
\end{abstract}

Keywords: Community Property, Hawalah, Court Decisio.

\begin{abstract}
Abstrak. Penulisan ini dilatarbelakangi oleh Pengalihan Utang (Hawalah) sebagai Upaya Legalitas Kepemilikan Harta Bersama atau di Indonesia disebut juga dengan harta gono-gini dimana hal tersebut merupakan kekayaan seluruhnya secara bulat yang diperoleh selama masa perkawinan. Permasalahan ini merupakan salah satu akibat hukum yang selalu hadir pasca perceraian adapun pengalihan hutang dalam harta bersama merupakan kasus yang jarang terjadi maka dari itu penulis bermaksud mengkaji lebih dalam mengenai harta bersama yang mengandung Hawalah atau pengalihan utang-piutang seperti gugatan yang masuk ke Pengadilan Agama Sukabumi pada perkara nomor. 0493/Pdt.G/2020/PA.Smi. Penelitian ini merupakan penelitian hukum normatif. Sumber dan jenis bahan hukum yang digunakan adalah bahan hukum primer yang didukung bahan hukum sekunder kemudian analisis dengan menggunakan metode normatif kualitatif dalam bentuk uraian untuk dapat ditarik kesimpulan agar mendapat kejelasan mengenai permasalahan yang diteliti. Berdasarkan hasil penelitian dan pembahasan dihasilkan kesimpulan yaitu, Pertama Pada pertimbangan hakim dalam perkara Nomor. 0493/Pdt.G/2020/PA.Smi. ini menggunakan pasal 97 Kompilasi Hukum Islam sebagai landasan hukum. Kedua, Pengalihan utang dalam upaya legalitas kepemilikan harta bersama tidak dapat dikabulkan oleh majelis hakim dikarenakan harta bersama tersebut belum dibagi secara rill. Ketiga, gugatan dikabulkan sebagian dikarenakan penggugat tidak sepenuhnya memberikan pembuktian hukum atas dalil-dalil gugatannya.
\end{abstract}

Kata Kunci: Harta Bersama, Hawalah, Putusan Pengadilan. 


\section{A. Pendahuluan}

Salah satu akibat hukum yang selalu hadir karena perceraian terutama di Indonesia adalah tentang harta bersama atau yang biasa disebut dengan harta gono-gini. Harta Bersama merupakan istilah yang merujuk kepada harta yang didapat oleh suami istri selama masa perkawinan. Adapun di dalam hukum adat terdapat pengertian sebagai berikut: harta bersama di Aceh biasa dinamakan dengan heureta sihaurekat, di Minangkabau (Padang) Sumatera Barat harta bersama disebut dengan harta suarang, kemudian di Sunda (Jawa Barat) disebut juga dengan guna kaya, tumpang kaya atau raja kaya, dan di jawa tengah maupun jawa timur disebut gono gini.

Harta Bersama terbentuk semenjak terjadinya perkawinan sampai putusnya perkawinan baik karena perceraian atau pun karena kematian. Adapun menurut Pasal 119 KUH Perdata Harta Bersama yakni penggabungan harta kekayaan seluruhnya secara mutlak, baik itu meliputi harta yang dibawa secara nyata (aktiva) ataupun berupa utang-piutang (Pasiva).

Adapun di dalam hukum Islam tidak ada yang membahas secara khusus tentang konsep harta bersama, akan tetapi sejauh ini para peneliti sebelumnya mencantumkan AlQuran Surat An-Nisa (4) ayat 32 sebagai landasan hukum atau bahan rujukan mengenai harta bersama. Allah menurunkan ayat ini (An-Nisa ayat 32) sebagai teguran untuk tidak beriri hati kepada ketetapan Allah namun hal tersebut masih bermakna umum sehingga penunjukannya tidak dikhusus kan hanya suami maupun istri, akan tetapi untuk semua laki-laki dan perempuan. Jika dalam kehidupan kesehariannya mereka berusaha, maka hasil yang didapatkan merupakan harta pribadi yang dikuasai penuh oleh pribadi masing-masing. Sebab turunnya ayat ini juga bukan membicarakan tentang harta bersama melainkan harta waris.

Pengalihan Utang disebut sebagai Hawalah, yakni menanggung utang piutang dari pihak pertama kepada pihak kedua yang dimana bank menjadi pihak ketiga. Hawalah disyariatkan oleh Islam dan diperbolehkan sebab ada nya maslahat untuk membantu dan memudahkan dalam kegiatan muamalah. Hawalah atau hiwalah berasal dari kata hawwala yang berarti ghayyara (mengubah) dan nawala (memindahkan), terkadang diartikan juga alsyahadah (kesaksian) dan al-kafalah (jaminan) menurut Ulama Hanafiyah, yang dimaksud dengan Hawalah ialah memindahkan tagihan dan tanggung jawab yang berutang kepada yang lain yang punya tanggung jawab kewajiban pula.

Fungsi dari harta bersama juga diperuntukan untuk membayar utang suami istri jika utang tersebut ada karena untuk kepentingan keluarga. Namun jika terjadinya suatu utang yang bersifat pribadi maka harus dituntut kepada suami atau istri yang membuat utang tersebut.

Hawalah Menurut Kompilasi Hukum Ekonomi Syari'ah Kompilasi Hukum Ekonomi Syariah (KHES) merupakan upaya kaum muslimin Indonesia untuk memberikan panduan bagi masyarakat yang berminat melaksanakan dan/atau menjadi pelaku ekonomi syariah di Indonesia. Kompilasi Hukum Ekonomi Syari'ah merupakan sumber rmateriil bagi para hakim dalam menyelesaikan perkara terkait ekonomi syari'ah termasuk Hawalah, Menurut Pasal 362 ayat (1) Kompilasi Hukum Ekonomi Syari'ah (KHES) mengenai rukun Hawalah adalah sebagai berikut: Muhil (Peminjam), Muhal (Pemberi Pinjaman), Muhal 'alaih (Penerima Hawalah), Muhal bih (Utang), dan Shigat (Akad). Sedangkan syarat pelaksanaan Hawalah dalam penggunaannya sebagai konsep akad pengalihan utang menggunakan syarat yang sama dengan syarat pelaksanaan akad pada umumnya.

Seperti yang terjadi di Pengadilan Agama Sukabumi, terdapat kasus terkait penyelesaian sengketa harta bersama, objek sengketa tersebut berupa tanah beserta bangunan yang diperoleh dengan pembelian secara kredit atas nama Tergugat dan kredit tersebut belum terbayar lunas sampai terjadinya perceraian, dimana Penggugat lah yang melanjutkan pembayaran kredit tersebut maka dari itu Penggugat mengajukan gugatan ke Pengadilan Agama Sukabumi dengan maksud dan alasan Penggugat mengajukan Gugatan ini adalah untuk menunjukkan legalitas atas harta kepada pihak Bank dan selanjutnya dibuat Surat Pemindahan Utang dari Tergugat kepada Penggugat. Dengan itu maka Pertimbangan hakim menjadi salah satu aspek terpenting dalam menentukan terwujudnya nilai dari suatu putusan 
hakim yang mengandung keadilan (ex aequo et bono) dan mengandung kepastian hukum, di samping itu juga mengandung manfaat bagi para pihak yang bersangkutan.

Berdasarkan latar belakang yang telah diuraikan, maka perumusan masalah dalam penelitian ini sebagai berikut:

1. Bagaimana Pembagian Harta Bersama pada Perkara Nomor.0493/Pdt.G/PA.Smi Ditinjau dari Kompilasi Hukum Islam?

2. Bagaimana Pengalihan Utang (Hawalah) sebagai Upaya Legalitas Kepemilikan Harta Bersama Ditinjau Dari Fatwa DSN MUI Nomor: 12/DSN-MUI/IV/2000?

3. Bagaimana Analisis Putusan Pengadilan Agama Sukabumi pada Perkara Nomor. 0493/Pdt.G/2020/Smi Perihal Harta Bersama yang Mengandung Hawalah? berikut:

Selanjutnya, tujuan dalam penelitian ini diuraikan dalam pokok-pokok sebagai

4. Untuk Mengetahui Pembagian Harta Bersama pada Perkara Nomor.0493/Pdt.G/PA.Smi Ditinjau dari Kompilasi Hukum Islam

5. Untuk Mengetahui Pengalihan Utang (Hawalah) sebagai Upaya Legalitas Kepemilikan Harta Bersama Ditinjau dari Fatwa DSN MUI Nomor:12/DSN-MUI/IV/2000

6. Untuk mengetahui Analisis Putusan Pengadilan Agama Sukabumi pada Perkara Nomor. 0493/Pdt.G/2020/Smi Perihal Harta Bersama yang Mengandung Hawalah.

\section{B. Metodologi Penelitian}

Pendekatan penelitian yang digunakan adalah pendekatan penelitian kualitatif kajian utama pada penelitian ini ada pada kedalaman masalah atau kasus yang diteliti untuk mendefinisikan suatu kasus dimana didalamnya terdapat data berupa deskriptif berupa hasil wawancara dari majelis hakim maka dari itu perlu adanya titik fokus yang spesifik dan unik dalam kasus tersebut. Dalam penelitian ini perihal harta bersama yang mengandung Hawalah menjadi kasus yang spesifik dan unik dengan objek penelitian yang akan menjadi bahan analisis penulis dalam penelitian ini adalah putusan Pengadilan Agama Sukabumi Nomor 0493/Pdt.G.2020/PA.Smi.

Sesuai dengan tujuan penelitiannya, maka penulis menggunakan tipe Penelitian Hukum Normatif. Sejalan dengan hal itu, yang dimaksudkan dengan penelitian hukum normatif adalah penelitian terhadap dunia norma atau aturan. Penelitian ini termasuk kedalam penelitian studi kasus yang dilakukan dengan mempelajari data primer dan data sekunder untuk mengungkap dan menggali data secara mendalam dan menganalisis secara intensif faktor-faktor yang dapat menyebabkan terjadinya kasus tersebut. Teknik pengumpulan data dalam penelitian ini adalah

Studi Pustaka Dalam penelitian ini penyusun melakukan studi pustaka dengan cara mempelajari Salinan putusan Nomor 0493/Pdt.G.2020/PA. Smi. Dan wawancara penyusun melakukan wawancara dengan subyek penelitian hakim Pengadilan Agama Karawang yang memutus dan memeriksa sengketa Harta Bersama putusan Nomor 0439/Pdt.G.2020/PA.Smi.

\section{Hasil Penelitian dan Pembahasan}

Pembagian Harta Bersama pada Perkara Nomor. 0493/Pdt.G/2020/Smi Ditinjau dari Kompilasi Hukum Islam, kedudukan harta bersama dalam perkawinan peraturannya sampai saat ini masih bersifat majemuk yang artinya meski harta tersebut sudah diatur dalam UndangUndang Nomor 1 Tahun 1974 namun tidak cukup untuk dijadikan landasan hukum maka dari itu pembagian harta bersama lebih banyak dituangkan dalam Kompilasi Hukum Islam. Pembagian Harta Bersama pada Perkara Nomor. 0493/Pdt.G/PA.Smi jika Ditinjau dari Kompilasi Hukum Islam merujuk kepada pasal 97 yaitu mengenai presentase pembagian harta bersama, Pembagian harta bersama tersebut dengan ketentuan presentase 50\%-50\% dimana suami atau istri akan mendapatkan setengah bagian dari harta bersama mereka sepanjang dalam perkawinan tersebut tidak adanya perjanjian yang mengatur perihal pembagian harta dan apabila kedua belah pihak tersebut telah melakukan kewajibannya sebagai suami maupun istri.

Pengalihan Utang (Hawalah) Sebagai Upaya Legalitas Kepemilikan Harta Bersama 
Ditinjau dari Fatwa DSN MUI Nomor: 12/DSN-MUI/IV/2000 pada konsideran Fatwa tersebut, dikatakan bahwa apabila seseorang tidak dapat membayar utang-utangnya secara langsung, ia boleh memindahkan penagihannya kepada pihak lain yang dalam hukum Islam disebut Hawalah, yaitu akad pengalihan utang dari satu pihak yang berutang kepada pihak lain yang mampu untuk melunasinya. Adapun menurut Sayyid Sabiq adalah "Pemindahan dari tanggungan muhil menjadi tanggungan muhal 'alaih" Jadi Al-Hawalah adalah pengalihan utang dari orang yang berutang kepada orang lain yang wajib menanggungnya.

Namun pada putusan hakim pengadilan agama sukabumi menimbang, bahwa permohonan pengalihan hutang meskipun ada klausul (Ketentuan Khusus) dengan surat persetujuan tergugat, tetap harus memenuhi syarat adanya pihak-pihak terkait sebagaimana Fatwa Dewan Syari'ah Nasional Nomor 12/DSN-MUI/IV/2000 jo Pasal 318 Kompilasi Hukum Ekonomi Syariah. Jadi, pengalihan Utang (Hawalah) sebagai Upaya Legalitas Kepemilikan Harta Bersama ditinjau dari Fatwa DSN MUI Nomor: 12/DSN-MUI/IV/2000 bisa dilakukan secara sah sepanjang memenuhi syarat-syarat seperti yang tertuang dalam ketentuan umum hawalah dalam fatwa DSN MUI tersebut.

Majelis Hakim berpendapat pembagian secara riil atas harta perkawinan yang dimaksud jelas tidak bisa dilakukan dan dipertimbangkan dengan alasan objek sengketa masih menjadi milik pihak ketiga yakni Bank meskipun terdapat bukti adanya pembelian dengan kredit yang telah diperjanjikan Tergugat dengan pihak Bank dan telah mendapatkan persetujuan Penggugat, belumlah dikatakan sempurna kecuali telah terpenuhinya masa kredit dan masa cicilan atau adanya pelunasan sebelum jatuh tempo.

Maka perhitungan harta bersama tersebut jelas dan dapat di bagi dengan masingmasing mendapat setengah bagian sesuai dengan pasal 97 Kompilasi Hukum Islam "Dimana seorang janda atau seorang duda karena perceraian akan mendapatkan masing-masing setengah bagian namun ketentuan tersebut bisa berubah atas pertimbangan hakim."

Analisis Putusan Pengadilan Agama Sukabumi pada Perkara Nomor. 0493/Pdt.G/2020/Smi Perihal Harta Bersama yang Mengandung Hawalah, dapat dipahami bahwa masalah yang diajukan pihak penggugat ialah mengenai status kepemilikan objek harta bersama. Adapun berdasarkan hasil wawancara dengan hakim pengadilan agama sukabumi beliau berpendapat bahwa terdapat dua pilihan untuk menyelesaikan perkara harta bersama tersebut yakni sebagai berikut:

Pertama, Sebelum penggugat (mantan istri) mengajukan gugatan ke pengadilan untuk menyatakan harta berupa tanah dan bangunan tersebut menjadi sepenuhnya miliknya, termasuk pelimpahan utang kredit didalam nya, hendaknya tergugat (mantan suami) menyatakan terlebih dahulu bahwa objek harta bersama tersebut telah sepenuhnya diberikan kepada penggugat atau telah dihibahkan kepada penggugat dengan memperhatikan ketentuan hukum yang berlaku yakni mendatangi kantor notaris atau pengadilan agama untuk dibuatkan akta otentik sehingga pemberian hibah atas bagian harta yang menjadi milik tergugat tersebut dinyatakan sah secara hukum.

Kedua, Objek harta bersama yang berupa tanah dan bangunan tersebut bisa dilelang oleh pihak bank, atau bisa menjualnya kepada seseorang dengan hasil pelelangan atau penjualan tersebut memiliki sisa dana setelah terpotong pembayaran utang kepada bank maka sisa dana tersebut bisa dibagi $1 / 2$ untuk mantan istri dan $1 / 2$ untuk mantan suami seperti ketentuan hukum yang berlaku yakni pada pasal 97 Kompilasi Hukum Islam atau bisa dibagi sesuai dengan kesepakatan masing-masing.

\section{Kesimpulan}

Setelah penulis analisis putusan tersebut berdasarkan pertimbangan hakim yang digunakan sebagai landasan hukum maka dapat ditarik kesimpulan sebagai berikut:

1. Pembagian Harta Bersama pada Perkara Nomor. 0493/Pdt.G/PA.Smi jika Ditinjau dari Kompilasi Hukum Islam merujuk kepada pasal 97 yaitu mengenai presentase pembagian harta bersama, Pembagian harta bersama tersebut dengan ketentuan presentase 50\%-50\% dimana suami atau istri akan mendapatkan setengah bagian dari harta bersama mereka sepanjang dalam perkawinan tersebut tidak adanya perjanjian 
yang mengatur perihal pembagian harta dan apabila kedua belah pihak tersebut telah melakukan kewajibannya sebagai suami maupun istri.

2. Pengalihan Utang (Hawalah) sebagai Upaya Legalitas Kepemilikan Harta Bersama ditinjau dari Fatwa DSN MUI Nomor: 12/DSN-MUI/IV/2000 bisa dilakukan secara sah sepanjang memenuhi syarat-syarat seperti yang tertuang dalam ketentuan umum hawalah dalam fatwa DSN MUI tersebut. Adapun jika harta bersama yang dimaksud belum dibagi secara riil sejak putusnya perkawinan maka mesti ada Akad sebagai Legalitas Kepemilikan Harta atau Legal Standing dahulu di depan Notaris atau Pengadilan Agama setempat.

3. Dalam analisis putusan Pengadilan Agama Sukabumi pada Perkara Nomor. 0493/Pdt.G/2020/PA.Smi Perihal Harta Bersama yang Mengandung Hawalah dapat disimpulkan bahwa hakim dalam pembagian harta bersama tersebut menggunakan kompilasi hukum islam khususnya pada pasal 97 sebagaimana mestinya dan Fatwa Dewan Syari'ah Nasional Nomor 12/DSN-MUI/IV/2000 untuk landasan hukum terkait syarat pengalihan utangnya. Adapun alasan putusan tersebut dikabulkan sebagian yakni dikarenakan penggugat tidak memenuhi syarat seperti yang tertuang dalam fatwa tersebut.

\section{Acknowledge}

Dalam kesempatan ini penulis mengucapkan terimakasih yang sebesar-besarnya kepada yang terhormat: Ibu DR. Neneng Nurhasanah, Dra., M.hum. Selaku Dosen Pembimbing satu, Bapak Muhamad Yunus, S.H.I., M.E.Sy, selaku dosen pembimbing dua yang selalu memberikan arahan dalam proses penyusunan skripsi. Bapak Djulia Herjanara, S.Ag., S.H., M.H. dan Bapak Dadi Aryandi, S.Ag. Selaku Ketua dan Wakil Ketua Pengadilan Agama Kota Sukabumi, terimakasih telah memberikan kesempatan kepada penulis untuk melaksanakan penelitian di Pengadilan Agama Sukabumi serta selalu memotivasi dan memberi inspirasi.

\section{Daftar Pustaka}

[1] Siska Lis Sulistiani, Hukum Perdata Islam (Penerapan Hukum Keluarga Dan Hukum Bisnis Islam Di Indonesia), Jakarta: Sinar Grafika, 2018.

[2] Panji Adam, Fikih Muamalah Maliyah : Konsep, Regulasi, Dan Implementasi, Bandung: PT.Refika Aditama, 2017.

[3] Julius Martin Saragih, Pertanggungjawaban Utang-Utang Persatuan Setelah Putusnya Perkawinan, Diponegoro Law Journal, Volume 6, Nomor 1, Tahun 2017

[4] Neneng Nurhasanah, Panji Adam, Hukum Perbankan Syariah Konsep dan Regulasi, (Jakarta Sinar Grafika), 2017.

[5] Mamat Ruhimat, "Teori Syirkah Dalam Pembagian Harta Bersama Bagi Istri Yang Berkarir Berdasarkan Undang-Undang Nomor 1 Tahun 1974 Dan Kompilasi Hukum Islam Serta Prakteknya Di Pengadilan Agama”, Jurnal 'Adliya Vol. 11, No. 1, 2017

[6] Muhammad Syafi'i Antonio, Bank Syariah Dari Teori Ke Praktek (Jakarta: Gema Insani Press, 2001).

[7] I Made Pasek Diantha, Metodologi Penelitian Hukum Normatif dalam Justifikasi Teori Hukum, Jakarta Prenada Media Group, 2016. 